Journal of Management and Economic
Studies
$\begin{gathered}\text { 2019, 1(3): 35-42 DOI: } 10.26677 / T R 1010.2019 .95 \\ \text { Journal Homepage: https://www.jomaes.org }\end{gathered}$

\title{
Measurement of Service Quality of Hotels in TRNC: Servqual Model
}

\section{Müjdat ERTÜRK}

Eskişehir Tepebaşı Ali Güven Vocational and Technical Anatolian High School, mujdate26@gmail.com

\begin{abstract}
One of the essential requirements for tourism enterprises to survive and increase their profitability by increasing their occupancy rates is to meet customer expectations through the services they render. A customer whose expectations have been met means a positive advertising tool for enterprises and a customer who will come again. Service quality, which is the most crucial factor in meeting customer expectations, is vital for enterprises. The present study was conducted to measure the difference between expectations and perceptions of service quality, therefore perceived service quality of foreign tourists visiting Turkish Republic of North Cyprus. The study was conducted with 408 tourists staying in the hotels most preferred by tourists in Kyrenia, Fagamusta and Bafra Regions. Survey technique was used as the data collection method. The difference between the service quality expected by the tourists and the service quality perceived by them after their experience was measured using the SERVQUAL scale. The data obtained were transferred to the computer, and a database was created; the results were then presented through various statistical analyses. The study concludes that the level of perceived service quality was below the level of expected service quality.
\end{abstract}

Key Words: Hotel Enterprises, Customer Expectations, Customer Perceptions, Service Quality, SERVQUAL Scale

\section{Introduction}

Improving working conditions, changes in lifestyles and rising living standards with increasing income levels are increasing the importance of the service sector in human life with each passing day. One of the most fundamental differences between today's information age and the industrial age is the importance and effectiveness of the service sector in the economy. The share of the service sector in the economy is now accepted as a measure of the development of countries.

Tourism, which has a significant share in the economies of countries, is one of the locomotive sectors of the service sector. Accommodation facilities form the basis of the tourism sector. Nowadays, it is imperative to keep the services offered by accommodation facilities at international standards. The maintenance of existing customers, the acquisition of new customers and the strengthening of relationships with these customers are only possible with a certain standard of service quality. 
Competition between countries makes itself felt in tourism as in every field. For this reason, increasing the quality and reliability of the services provided in accommodation establishments, which are the lifeblood of the tourism sector, expanding the types of services, and creating a product mix suitable for the expectations of the tourists, are of great importance for taking the lead in the competition. In short, to increase competitiveness in the tourism sector, it is necessary to increase the perceived service quality effectively.

\section{Conceptual Framework and Related Literature}

The service is non-physical products produced by man and machines and directly benefits consumers (Skinner, 1990). Kotler (1997) defined service as 'an action or an activity which can be offered by a party to another party, which is intangible and can not affect any ownership (Kotler, 1997). According to another definition, services are abstract activities which cause satisfaction when they are marketed to industrial users or consumers, which are not related to the sale of a product or any other services, and which can be independently identified (Powers, 1997). Payne defined service as processes that did not result in the ownership of the property being changed (Payne, 1993). Edvardsson stated that there are different definitions of the concept of service, but activities, actions, processes, and interactions are the most emphasized concepts in the definitions (Edvardsson, 2005).

People live together with the concept of service which manifests itself in different forms at every stage of their lives. Service is an inevitable consequence of people living together, and it is possible to talk about service related to any subject directly or indirectly about people. From this point of view, it can be said that service is an ancient concept. The service is an abstract concept, it cannot be inventoried in any way, it cannot be stored, it cannot be standardized, it goes directly from the producer to consumer, and it does not have a relationship with visuality, objectivity, and property (Assael, 1993). Features such as abstractness, human involvement, non-standardization, concurrency, and variable demands distinguish service from goods.

Service quality is vital for the survival of hotels in a competitive environment, and this importance is increasing day by day. According to Reeves and Bednar (1994), quality is suitability for use. Deming (2000) defined quality as customer judgments about the goods or services offered by the enterprise. Grönroos (1984) defined service quality as the values resulting from the comparison of customer expectations and perceived quality. Service quality is a measure of how well the expectations of customers are met (Lewis and Booms, 1983). Whether the service is of good quality can be measured by the suitability of the service to customer expectations (Parasumaran et al., 1985). Given all these definitions about service quality, it can be said that to determine service quality, customer expectations and the perceptions that occur after the consumption of service need to be compared (Lee et al., 2000). It is possible to examine service quality in two dimensions: expected service quality and perceived service quality. Expected service quality is the expectations of a customer from an enterprise for the service they purchased. On the other hand, perceived service quality is the opinions of the customers about the service quality, and the degree of customer satisfaction is primarily determined by these opinions (Ghobadian et al., 1994). The relationship between expected service and perceived service can be explained as follows (Parasuraman et al., 1985).

If Expected Service > Perceived Service, perceived quality is not satisfactory,

If Expected Service $=$ Perceived Service, perceived quality is satisfactory,

If Expected Service < Perceived Service, perceived quality is satisfactory. As this difference increases, the ideal service quality is approached. 
Since the concept of service quality has gained importance, models and scales have been developed for the measurement of service quality. The first of these models was the Technique and Functional Quality Model developed by Grönroos in 1984. The second model is the Gaps Model developed by Parasuraman, Zeithaml, and Bery (1985). The Attribute Service Quality Model developed by Haywood-Farmer (1988), the Servperf-Performance-Based Model developed by Cronin and Taylor (1992), the Service Quality Model Based on an Ideal Value Standard developed by Mattsson (1992), the Evaluated Performance and Normed Quality Model developed by Teas (1993), the IT Alignment Model developed by Berkley and Gupta (1994), the Attribute and Overall Affect Model developed by Dabholkar (1996), the Model of Perceived Service Quality and Satisfaction developed by Spreng and Mackoy (1996), the Pivotal, Core and Peripheral Attribute Model developed by Philip and Hazlett (1997), the Service Quality, Customer Value and Customer Satisfaction Model developed by Oh (1999), the Antecedents and Mediator Model developed by Dabholkar et al. (2000), and the Internal Service Quality Model developed by Frost and Kumar (2000) are the models used in the measurement of service quality.

Among these models, the Gaps Model developed by Parasuraman et al. and the Servqual scale measuring service quality in this model is the most accepted model and scale. The Servqual first measures the expectations of customers from the service they want to purchase and then their perceptions of the service after receiving the service. The difference between expectations and perceptions indicates the level of service quality. The Servqual scale contains 22 items in 5 different sizes (tangibles, reliability, responsiveness, assurance, and empathy) to measure expected and perceived service quality. The scale also includes a part for customers to determine the order of importance of the dimensions and in this part; customers are asked to allocate 100 points to five service quality dimensions to demonstrate the relative importance of dimensions. As a result of the evaluations made by customers by considering the order of importance of the five dimensions of the scale, the most critical dimension for customers is reliability, followed by responsiveness, assurance, empathy, and tangibles (Parasuraman et al., 1991: 431).

\section{Method}

\section{Purpose of the Research}

The present study aims to determine the perceived service quality of foreign tourists who received service from hotels in TRNC. The hypothesis of the research was determined as follows:

H1: The service quality perceived by the tourists participating in the study is equal to the service quality expected by them.

\section{Importance of the Research}

The hotels in the Kyrenia, Fagamusta and Bafra regions, where tourists usually stay, were included in the research. Similar studies were carried out in one or more hotels in the same region. The fact that this research was carried out in many hotels in different regions can be said to attract attention as a factor increasing the importance of research.

\section{Scope and Limitations}

The scope of the research was geographically limited due to the spread of tourists over a wide area visiting TRNC. For this reason, the research was carried out with tourists staying in hotels in Kyrenia, Fagamusta and Bafra Regions. The reason for choosing these cities is that tourists generally prefer these regions. 


\section{Population and Sample}

The data of this study were obtained from foreign tourists visiting TRNC. In this direction, 1.759.625 tourists visiting TRNC and staying in TRNC in 2018 constituted the universe of the research. Such an extensive scope of research raises some challenges to reach the entire area and visitors. Therefore, sampling was made from this determined population. Four hundred eight questionnaires were assessed in the study.

\section{Data Collection}

The 7-point Likert type Servqual Service Quality Scale developed by Parasuraman, Zeithaml and Berry was utilized for data collection. The survey consists of three parts. The first part contains the Servqual scale consisting of 22 items and measures the service quality expected by the participants. The second part includes the Servqual scale again and measures the quality of the services perceived by the participants. The third part contains descriptive information, such as age, gender, educational status, marital status, occupational status, the frequency of accommodation in hotels, the type of hotel, and the country of origin. The participants were also asked to rate the dimensions according to the importance they attach to the dimensions.

Responses were collected in two stages. In the first stage, the service quality expected by the tourists was measured during their transfer from the airports to the hotels. In the second stage, the same surveys were re-distributed to the tourists on their way to the airports after their holidays were over to measure perceived service quality.

The Cronbach Alpha coefficient of the study was determined as 0.9615 . This value indicates statistical reliability for the social sciences.

\section{Data Analysis}

A database was created on the computer with the answers of the participants to the measurement tool. The data obtained from the study were interpreted using SPSS 17 program through various statistical methods such as frequency, mean, mean differences, t-test, ANOVA test, and Tukey test.

\section{Personal Information about the Participants}

Table 1. Demographic Characteristics of Participants and Descriptive Statistics

\begin{tabular}{|c|c|c|c|c|c|}
\hline Sex & $\mathbf{n}$ & $\%$ & Age & $\mathbf{n}$ & $\%$ \\
\hline Male & 197 & 48,28 & $14-$ & 3 & 0,70 \\
\hline Female & 211 & 51,72 & $15-24$ & 18 & 4,42 \\
\hline Total & 408 & 100 & $25-34$ & 74 & 18,14 \\
\hline Marital Status & $\mathbf{n}$ & $\%$ & $35-44$ & 121 & 29,67 \\
\hline Married & 184 & 45,10 & $45-54$ & 96 & 23,54 \\
\hline Single & 224 & 54,90 & $55-64$ & 74 & 18,13 \\
\hline Total & 408 & 100 & $65+$ & 22 & 5,40 \\
\hline Occupation & $\mathbf{n}$ & $\%$ & Total & 408 & 100 \\
\hline Manager & 89 & 21,81 & Educational Status & $\mathbf{n}$ & $\%$ \\
\hline Business owner & 137 & 33,57 & Primary School & 8 & 1,96 \\
\hline White-collar worker & 72 & 17,64 & Secondary School & 42 & 10,30 \\
\hline Blue-collar worker & 24 & 5,89 & Associate Degree & 86 & 21,07 \\
\hline
\end{tabular}




\begin{tabular}{|c|c|c|c|c|c|}
\hline Student & 12 & 2,95 & Bachelor's Degree & 204 & 50,00 \\
\hline Retired & 39 & 9,55 & Postgraduate & 52 & 12,75 \\
\hline Housewife & 18 & 4,42 & Doctor's Degree & 16 & 3,92 \\
\hline Other & 17 & 4,17 & Total & 408 & 100 \\
\hline Total & 408 & 100 & $\begin{array}{l}\text { Duration of } \\
\text { Accommodation }\end{array}$ & $\mathbf{n}$ & $\%$ \\
\hline Nationality & $\mathbf{n}$ & $\%$ & 1-5 Days & 328 & 80,39 \\
\hline Turkish & 351 & 86,02 & 6-10 Days & 54 & 13,24 \\
\hline Israel & 24 & 5,88 & 11-15 Days & 26 & 6,37 \\
\hline Iran & 19 & 4,67 & Total & 408 & 100 \\
\hline Russian & 14 & 3,43 & & & \\
\hline Total & 408 & 100 & & & \\
\hline
\end{tabular}

Table 1 presents the results of the frequency and percentage analysis of the demographic characteristics of the participants. According to Table 1, of the respondents, 51,72\% were women, $54,90 \%$ were single, $33,57 \%$ were business owner, $86,02 \%$ were Turkish, $29,67 \%$ were in the $35-44$ age range, $50,00 \%$ had a bachelor's degree, and $80,39 \%$ stayed in the hotels for $1-5$ days.

\section{Findings}

The Order of Importance of the Dimensions

Table 2. The Order of Importance of the Dimensions

\begin{tabular}{|l|c|}
\hline Dimensions & Frequency \\
\hline Tangibles & 0,16 \\
\hline Reliability & 0,24 \\
\hline Responsiveness & 0,21 \\
\hline Assurance & 0,20 \\
\hline Empathy & 0,19 \\
\hline TOTAL & $\mathbf{1 0 0}$ \\
\hline
\end{tabular}

Table 2 presents the order of importance of the dimensions for the participants. According to Table 2, the participants considered the "reliability" dimension as the most important dimension (24\%) whereas the "tangibles" dimension as the least important dimension (16\%). 
Table 3. Averages of Dimensions, Differences, and Mean of Differences, Servqual Score

\begin{tabular}{|c|c|c|c|c|c|c|c|}
\hline Dimension & No & Perception & Expectation & Difference & $\begin{array}{c}\text { Order } \\
\text { of } \\
\text { Importa } \\
\text { nce } \\
\end{array}$ & $\begin{array}{c}\text { Weight } \\
\text { ed } \\
\text { Differe } \\
\text { nce } \\
\end{array}$ & $\begin{array}{c}\text { Weighted } \\
\text { Servqual } \\
\text { Score }\end{array}$ \\
\hline \multirow{4}{*}{ Tangibles } & 1 & 4,95 & 5,95 & $-1,00$ & \multirow{5}{*}{0,16} & \multirow{5}{*}{$-0,06$} & \\
\hline & 2 & 5,16 & 5,11 & 0,05 & & & \\
\hline & 3 & 5,44 & 5,83 & $-0,39$ & & & \\
\hline & 4 & 5,32 & 5,51 & $-0,19$ & & & \\
\hline \multicolumn{2}{|l|}{$\begin{array}{l}\text { Average of } \\
\text { Dimension }\end{array}$} & 5,22 & 5,60 & $-0,38$ & & & \\
\hline \multirow{5}{*}{ Reliability } & 5 & 5,34 & 6,40 & $-1,06$ & \multirow{6}{*}{0,24} & \multirow{6}{*}{$-0,27$} & \\
\hline & 6 & 5,36 & 6,37 & $-1,01$ & & & \\
\hline & 7 & 5,28 & 6,47 & $-1,19$ & & & \\
\hline & 8 & 5,25 & 6,38 & $-1,13$ & & & \\
\hline & 9 & 4,95 & 6,27 & $-1,32$ & & & \\
\hline \multicolumn{2}{|l|}{$\begin{array}{l}\text { Average of } \\
\text { Dimension }\end{array}$} & 5,24 & 6,38 & $-1,14$ & & & \\
\hline \multirow{4}{*}{ Responsiveness } & 10 & 5,69 & 6,36 & $-0,67$ & \multirow{5}{*}{0,21} & \multirow{5}{*}{$-0,10$} & \\
\hline & 11 & 5,89 & 6,27 & $-0,38$ & & & \\
\hline & 12 & 5,98 & 6,32 & $-0,34$ & & & \\
\hline & 13 & 5,79 & 6,21 & $-0,42$ & & & $-0,15$ \\
\hline \multicolumn{2}{|l|}{$\begin{array}{l}\text { Average of } \\
\text { Dimension }\end{array}$} & 5,84 & 6,29 & $-0,45$ & & & \\
\hline \multirow{4}{*}{ Assurance } & 14 & 5,41 & 6,24 & $-0,83$ & \multirow{5}{*}{0,20} & \multirow{5}{*}{$-0,19$} & \\
\hline & 15 & 5,39 & 6,27 & $-0,88$ & & & \\
\hline & 16 & 5,61 & 6,46 & $-0,85$ & & & \\
\hline & 17 & 5,12 & 6,34 & $-1,22$ & & & \\
\hline \multicolumn{2}{|l|}{$\begin{array}{l}\text { Average of } \\
\text { Dimension }\end{array}$} & 5,38 & 6,33 & $-0,94$ & & & \\
\hline \multirow{5}{*}{ Empathy } & 18 & 5,58 & 6,23 & $-0,65$ & \multirow{6}{*}{0,19} & \multirow{6}{*}{$-0,13$} & \\
\hline & 19 & 5,63 & 6,14 & $-0,51$ & & & \\
\hline & 20 & 5,47 & 6,13 & $-0,66$ & & & \\
\hline & 21 & 5,26 & 6,22 & $-0,96$ & & & \\
\hline & 22 & 5,53 & 6,08 & $-0,55$ & & & \\
\hline \multicolumn{2}{|l|}{$\begin{array}{l}\text { Average of } \\
\text { Dimension }\end{array}$} & 5,49 & 6,16 & $-0,67$ & & & \\
\hline \multicolumn{2}{|l|}{$\begin{array}{l}\text { GENERAL } \\
\text { AVERAGE }\end{array}$} & 5,43 & 6,15 & $-0,72$ & 100 & $-0,75$ & \\
\hline
\end{tabular}

Table 3 presents the averages of perceptions and expectations of the respondents, the differences between them, the averages of perceptions and expectations for each dimension, weighted means according to the importance of dimensions, and weighted Servqual score. According to the information given in Table 3, the unweighted service quality ranking is 
tangibles $(-0,38)$, responsiveness $(-0,45)$, empathy $(-0,67)$, assurance $(-0,94)$ and reliability $(-1,14)$. Accordingly, the unweighted Servqual score is $(-0.72)$.

The weighted service quality ranking, on the other hand, is tangibles $(-0,06)$, responsiveness ($0,10)$, empathy $(-0,13)$, assurance $(-0,19)$, and reliability $(-0,27)$. Accordingly, the weighted Servqual score is $(-0,15)$. Thus, the $\underline{\mathbf{H}_{1}}$ hypothesis was rejected.

\section{Conclusion and Recommendations}

Overall, the mean score from the dimension of expected service quality is 6,15, and the mean score from the dimension of perceived service quality is 5.43 (Table 3). Therefore, there is a difference of 0.72 between the mean scores of both dimensions. Considering the order of importance of the dimensions, this difference is 0,15 . This difference can be considered to represent an acceptable level of service quality. However, to further minimize this difference, it is important to emphasize:

1) Enterprises should render the services they promise to their customers and not carry out advertising activities to deceive their customers.

2) Enterprises should continually guide and check their employees to address more closely their customers' problems.

3) Employees who give confidence to customers should be employed; employees that exhibit unreliable behaviours should be warned; if necessary, their work contracts should be terminated.

4) It is vital for enterprises to provide their employees with a healthy working environment and adequate equipment.

5) Enterprises should pay particular attention to the customers experiencing problems and deal with their problems until they are resolved.

6) The architecture and landscaping of the enterprise must match the services provided; a link must be established between appearance and service.

7) Enterprises should inform their customers about the time of the services provided; they should ensure that every customer who wishes can benefit from these services.

8) Even if employees are busy, they should not remain indifferent to the requests of customers, they should inform customers about when they can help them about their requests, and once they are done with their current task, they should take care of the customer's request right away.

\section{REFERENCES}

Assael, H.(1993). Marketing Principles and Strategy, Second Edition, Orlando: The Dryden Press

Berkley, B. J. and Gupta, A. (1994). Improving Service Quality with Information Technology. International Journal of Information Management, 14(2):109-121.

Cronin, J. J. and Taylor, S. A. (1992). Measuring Service Quality: A Re-Examination And Extension. Journal Of Marketing, 56(3):55-68.

Dabholkar, P. A., Shepherd, C. D. and Thorpe, D.I. (2000). A Comprehensive Framework For Service Quality: An Investigation of Critical Conceptual and Measurement Issues Through a Longitudinal Study, Journal of Retailing, 76(2):131 -139.

Dabholkar, P.A., (1996). Consumer Evaluations of New Technology-based Selfservice Operations: An Investigation of Alternative Models. International Journal of Research in Marketing, 13(1):29-51. 
Deming, W. E. (2000) Out of Crisis, Cambridge: MIT Press

Edvardsson, B., (2005). Service Quality: Beyond Cognitive Assessment, Managing Service Quality: An International Journal, 15(2):127-131.

Frost, F.A. and Kumar, M. (2000). INTSERVQUAL: An Internal Adaptation of the GAP Model in a Large Service Organization, Journal of Services Marketing, 14.(5):358-377.

Ghobadian, A., Speller S., and Jones M. (1994). Service Quality: Concepts and Models, International Journal of Quality ve Reliabilitiy Management, 11(9): 43-66.

Grönroos, C. (1984). A Service Quality Model and Its Marketing Implications, European Journal of Marketing, 18 (4):36-44.

Haywood-Farmer, J. (1988). A conceptual model of service quality. International Journal of Operations and Production Management., 8(6):19-29.

Kotler, P. (1997). Marketing Management: Analysis, Planning, Implementation and Control (9th Edition). New Jersey: Prentice Hall International.

Lee, H., Lee, Y, and Yoo, D. (2000). The Determinants of Perceived Service Quality and Its Relationship With Satisfaction, Journal of Service Marketing, 14(3): 217-231.

Lewis, R. C. and Booms, B. H. (1983). The marketing aspect of service quality, pp. 99-107, In L. Berry, G. Shostack, and G. Upah, (Eds), Emerging Perspective on Service Marketing. Chicago: American Marketing Association.

Mattson, J. (1992). A Service Quality Model Based on Ideal Value Standard. International Journal of Industry Management,3(3):18-33.

Oh, H. (1999). Service Quality, Customer Satisfaction and Customer Value: A Holistic Perspective. International Journal of Hospitality Management, 18(1):67-82.

Parasuraman, A., Zeithaml, V. A. and Berry, L. L. (1991). Refinement and Reassessment of the SERVQUAL Scale. Journal of Retailing, 67 (4): 420-450.

Parasuraman, A., Zeithaml, V.A., and Berry, L.L.(1985). A Conceptual Model of Service Quality and Its Implications for Future Research, The Journal of Marketing, 49(4):41-50.

Payne, A. (1993). The Essence of Service Marketing, United States: Prentice-Hall, Inc.

Philip, G. and Hazlett, S.A. (1997). The Measurement of Service Quality: A New P-C-P Attributes Model. International Journal of Quality and Reliability Management, 14(3): 260-286.

Powers, T. (1997). Marketing Hospitality, New York: John Wiley \& Sons.

Reeves, C. A., and Bednar, D.A., (1994). Defining Quality: Alternatives and Implications, The Academy of Management Review, 19(3): 419-445.

Skinner, S. J. (1990). Marketing, Boston: Houghton Mifflin Company

Spreng, R.A. and Mackoy, R.D. (1996). An Empirical Examination of a Model of Perceived Service Quality and Satisfaction. Journal of Retailing, 72(2):201 -214.

Teas, K. R. (1993). Expectations, Performance Evaluation and Consumers' Perceptions of Quality. Journal of Marketing,57(4):18-34. 